\title{
Mengembangkan Kemampuan Komunikasi Matematik Siswa melalui Strategi Think Talk Write
}

\author{
Reni Nuraeni ${ }^{1}$ \\ STKIP Garut \\ Irena Puji Luritawaty ${ }^{2}$ \\ STKIP Garut
}

\begin{abstract}
ABSTRAK
Penelitian ini didasarkan pada permasalahan rendahnya kemampuan komunikasi matematik siswa. Sebagai alternatif dari permasalahan tersebut, dilakukan penelitian dengan penerapan strategi think talk write dalam pembelajaran. Penelitian ini mengkaji pencapaian kemampuan komunikasi matematik siswa yang memperoleh strategi pembelajaran think talk write dengan pembelajaran konvensional. Penelitian ini merupakan penelitian kuasi eksperimen dengan menggunakan teknik purposive sampling. Populasi dalam penelitian ini adalah seluruh siswa salah satu MTs swasta di Kabupaten Garut. Untuk sampel penelitiannya diambil dua kelas tingkat VII, satu kelas sebagai kelas kontrol dan satu kelas lainnya sebagai kelas eksperimen. Instrumen yang digunakan dalam penelitian berupa tes kemampuan komunikasi matematik. Analisis data dilakukan dengan uji statistik deskriptif dan inferensial. Hasil penelitian menunjukkan bahwa pencapaian kemampuan komunikasi matematik siswa yang memperoleh strategi pembelajaran think talk write lebih baik daripada siswa yang memperoleh pembelajaran konvensional.
\end{abstract}

\section{Kata kunci: Kemampuan komunikasi matematik, strategi Think Talk Write}

\begin{abstract}
This research is based on the issues of mathematical communication skills students lack. As an alternative to that problem, conducted research with the implementation of the strategy think talk write in the study. This research examines the achievements of mathematical communication skills students acquire learning strategies think talk write with conventional learning. This research was quasi experimental study by using purposive sampling technique. The population in this study are all the students one of MTs in Garut. The research sample is taken for two grade levels VII, one class as the control class and one other class as a experiment class. The instruments used in the study of mathematical communication ability tests. The data analysis done with test descriptive statistics and inferensial. The results showed that the achievement of mathematical communication skills students acquire learning strategies think talk write better than students who get conventional instruction.
\end{abstract}

Keywords: Mathematical communication skill, Think Talk Write strategy

\section{PENDAHULUAN}

Matematika merupakan salah satu mata pelajaran yang sangat penting, ini dibuktikan matematika selalu ada di setiap jenjang pendidikan. Dalam kehidupan sehari-hari, kegiatan manusia tidak terlepas dari matematika, misalkan pada bidang perdagangan selalu melibatkan proses perhitungan seperti penjumlahan, pengurangan, perkalian, dan pembagian. Matematika juga digunakan dalam pengembangan ilmu pengetahuan yang lain seperti kesehatan, perekonomian, perindustrian, dan masih banyak lainnya.

Mengingat hal tersebut, pencapaian tujuan pembelajaran matematika harus menjadi prioritas utama. Dimana siswa memiliki kemampuan dalam bermatematika setelah proses pembelajaran berlangsung, yang selanjutnya dapat menjadi bekal siswa dalam kehidupan sehari-harinya. Ini menjadi tugas guru, bagaimana menciptakan pembelajaran yang kondusif yang dapat membantu pencapaian tujuan pembelajaran matematika. Oleh karena itu, pembelajaran 
matematika harus diarahkan untuk memenuhi

kebutuhan masa kini dan kebutuhan masa yang akan datang (Sumarmo, 2013).

Menurut Kurikulum Tingkat Satuan

Pendidikan (KTSP, 2006), tujuan pembelajaran matematika yaitu:

1. Memahami konsep matematika, menjelaskan keterkaitan antar konsep dan mengaplikasikan konsep atau algoritma, secara luwes, akurat, efisien, dan tepat, dalam pemecahan masalah.

2. Menggunakan penalaran pada pola dan sifat, melakukan manipulasi matematika dalam membuat generalisasi, menyusun bukti, atau menjelaskan gagasan dan pernyataan matematika.

3. Memecahkan masalah yang meliputi kemampuan memahami masalah, merancang model matematika, menyelesaikan model dan menafsirkan solusi yang diperoleh.

4. Mengkomunikasikan gagasan dengan simbol, tabel, diagram, atau media lain untuk memperjelas keadaaan atau masalah.

5. Memiliki sikap menghargai kegunaan matematika dalam kehidupan, yaitu memiliki rasa ingin tahu, perhatian, dan minat dalam mempelajari matematika, serta sikap ulet dan percaya diri dalam pemecahan masalah.

Dari uraian di atas dapat dilihat, bahwa salah satu tujuan pembelajaran matematika adalah siswa memiliki kemampuan komunikasi matematik. Selain itu, (NCTM) National Council of Teachers of Mathematics (2000: 29) dalam buku berjudul 'Principles and Standard for School Mathematics' menyatakan bahwa standar proses pembelajaran matematika terdiri dari pemecahan masalah (problem solving), penalaran dan pembuktian (reasoning and proof), komunikasi matematis (communication), keterkaitan dalam matematika (connection), dan representasi (representation).

Greenes dan Schulman (Priyambodo, 2008: 3) menjelaskan bahwa komunikasi matematik merupakan kekuatan sentral bagi siswa dalam merumuskan konsep dan strategi matematika; sebagai modal keberhasilan siswa terhadap pendekatan dan penyelesaian dalam eksplorasi dan investigasi matematika; dan komunikasi sebagai wadah bagi siswa untuk memperoleh informasi atau membagi pikiran, menilai dan mempertajam ide untuk meyakinkan orang lain.

Hal senada juga dijelaskan oleh Baroody (1993) bahwa terdapat dua alasan mengapa komunikasi penting. Alasan pertama adalah matematika tidak hanya sekedar alat bantu berpikir, alat untuk menemukan pola, menyelesaikan masalah atau mengambil kesimpulan, akan tetapi matematika juga merupakan suatu alat yang tidak ternilai untuk mengkomunikasikan berbagai ide dengan jelas, dengan tepat, dan dengan ringkas tapi jelas. Alasan kedua adalah pembelajaran matematika merupakan aktivitas sosial dan juga sebagai wahana interaksi antara siswa dengan siswa dan antara guru dengan siswa.

Pentingnya komunikasi matematika juga diungkapkan oleh Lindquist dan Elliot (1996) yang menyatakan bahwa kita memerlukan komunikasi dalam belajar matematika jika hendak meraih secara penuh tujuan sosial seperti belajar seumur hidup dan matematika untuk semua orang. Apabila kita sepakat bahwa matematika merupakan suatu bahasa dan bahasa tersebut sebagai bahasa terbaik dalam komunitasnya, maka mudah dipahami bahwa komunikasi adalah faktor penting dari mengajar, belajar, dan mengakses matematika. Tanpa komunikasi dalam matematika maka kita akan memiliki sedikit keterangan, data, dan fakta tentang 
pemahaman siswa dalam melakukan proses dan aplikasi matematika.

Namun pada kenyataannya, kemampuan komunikasi matematika pun masih rendah di kalangan siswa. Berdasarkan hasil yang diperoleh siswa Indonesia di ajang TIMSS tahun 2007, terlihat bahwa siswa Indonesia masih lemah dalam hal komunikasi matematis, sebagaimana yang terjadi dengan jawaban siswa pada salah satu soal tentang membaca data dalam diagram lingkaran dan menyajikannya dalam bentuk diagram batang. Hanya $14 \%$ siswa peserta Indonesia yang mampu menjawab benar, sementara di tingkat internasional terdapat $27 \%$ siswa yang menjawab benar.

Hasil riset Bergeson dalam penelitian Satriawati (2006:24) menyatakan bahwa siswa sulit mengomunikasikan informasi visual terutama dalam mengomunikasikan sebuah lingkungan tiga dimensi (misalnya, sebuah bangunan terbuat dari balok kecil) melalui alat dua dimensi (misalnya, kertas dan pensil) atau sebaliknya. hasil penelitian Osterholm (2006:292) menyatakan bahwa siswa tampaknya kesulitan mengartikulasikan alasan dalam memahami suatu bacaan. Ketika diminta mengemukakan alasan logis tentang pemahamannya, siswa kadang-kadang hanya tertuju pada bagian kecil dari teks dan menyatakan bahwa bagian ini (permasalahan yang memuat simbol-simbol) tidak mengerti, tetapi tidak memberikan alasan atas pernyataannya tersebut. Selain itu, menurut hasil penelitian Ahmad, Siti, dan Roziati dalam penelitian Maryani (2011:24) menunjukkan bahwa mayoritas dari siswa tidak menuliskan solusi masalah dengan menggunakan bahasa matematis yang benar. Masih banyaknya siswa yang tidak menuliskan solusi tersebut menjadikan komunikasi intrapersonal (pemrosesan simbol pesan-pesan) dan interpersonal (proses penyampaian pesan) penting dalam menginterpretasikan istilah untuk memecahkan masalah matematika.
Sesuai dengan Peraturan Pemerintah RI Nomor 19 Tahun 2005 Bab IV Standar Proses Pasal 19 ayat 1, tentang Standar Nasional Pendidikan menyatakan bahwa proses pembelajaran pada satuan pendidikan diselenggarakan secara interaktif, inspiratif, menyenangkan, menantang, memotivasi peserta didik untuk berpartisipasi aktif, serta memberikan ruang yang cukup bagi prakarsa, kreativitas, sesuai dengan bakat, minat, dan perkembangan fisik serta psikologis peserta didik.

Dari uraian di atas, dapat disimpulkan bahwa guru dalam proses pembelajaran harus menciptakan suasana pembelajaran yang kondusif dan membantu siswa dalam mencapai tujuan pembelajaran matematika, dalam hal ini terutama kemampuan komunikasi matematik siswa. Salah satu strategi pembelajaran yang diperkirakan baik untuk diterapkan dalam mengembangkan kemampuan komunikasi matematik siswa adalah strategi pembelajaran kooperatif Think Talk Write.

Pembelajaran Think Talk Write diperkenalkan oleh Huinker dan Laughlin pada tahun 1996. Pada dasarnya pembelajaran tersebut dibangun melalui tiga aktivitas utama yaitu berpikir (Think), berbicara (Talk), dan menulis (Write). Tahap think diawali dengan kegiatan siswa memikirkan permasalahan yang diberikan. Hal tersebut membuat siswa harus aktif mengeksplorasi kemampuannya untuk memahami masalah, mengidentifikasi data yang diperlukan untuk memecahkan masalah, memunculkan beragam ide matematika, dan menyatakannya dalam bentuk tulisan untuk didiskusikan dengan teman sekelompoknya.

Pada tahap talk, siswa harus aktif berbicara dalam diskusi untuk menjelaskan hasil dari tahap think kepada temannya. Siswa harus yakin terhadap kemampuannya terkait dengan ide yang sudah didapatkannya. Siswa pun harus mampu menyampaikan pendapatnya dengan baik. Setelah itu, siswa 
selanjutnya masuk ke tahap write yaitu menuliskan hasil dari diskusi yang telah dilakukan dengan teman-temanya dengan bahasanya sendiri. Pada tahap ini siswa dituntut untuk selektif dalam menentukan solusi yang paling tepat untuk dicatat dalam buku catatannya.

Hal tersebut sejalan dengan indikator komunikasi matematik yang diutarakan oleh Anggraeni (2012: 13) yaitu menyatakan situasi ke dalam bentuk model matematika, membuat situasi masalah ke dalam bahasa sendiri, dan menjelaskan ide matematis scara tulisan.

Berdasarkan uraian di atas, penulis tertarik untuk melakukan penelitian yang berfokus pada pembelajaran yang diduga dapat mengembangkan kemampuan komunikasi matematik siswa dengan judul "Mengembangkan Kemampuan Komunikasi Matematik Siswa melalui Strategi Think Talk Write."

Berdasarkan latar belakang masalah yang telah diuraikan, masalah dalam penelitian ini adalah "Apakah penerapan strategi think talk write dalam pembelajaran matematika dapat mengembangkan kemampuan komunikasi matematik siswa?". Rumusan masalah tersebut dijabarkan dalam pertanyaan penelitian, "Apakah pencapaian kemampuan komunikasi matematik siswa yang pembelajarannya menggunakan strategi think talk write lebih baik daripada siswa yang menggunakan pembelajaran konvensional?"'

Sebagaimana telah diuraikan di atas bahwa kemampuan komunikasi matematik siswa sangat penting dalam pembelajaran matematika, maka manfaat yang diharapkan dari penelitian ini adalah sebagai berikut:

1. Bagi siswa, diharapkan penerapan strategi think talk write membantu dalam mengembangkan kemampuan komunikasi matematik siswa.

2. Bagi guru, penelitian ini dapat dijadikan bahan masukan dalam rangka pemilihan model pembelajaran yang cocok untuk mengembangkan

kemampuan

komunikasi matematik siswa.

3. Bagi peneliti, penelitian ini dapat dijadikan sebagai landasan berpijak untuk melakukan penelitian di ruang lingkup yang lebih luas, serta memberikan kontribusi pada pengembangan pembelajaran matematika dalam upaya meningkatkan kemampuan komunikasi matematik siswa.

\section{Kemampuan Komunikasi Matematik}

Kemampuan komukasi matematik adalah kemampuan siswa dalam hal menjelaskan suatu algoritma dan cara unik untuk pemecahan masalah, mengkonstruksi dan menjelaskan grafik, kata-kata atau kalimat, persamaan, tabel, dan sajian secara fisik (Schoen, Bean \& Ziebarth, 1996: 170). Selain itu Greenes dan Schulman (1996: 159) menyatakan bahwa komunikasi matematik adalah kemampuan (1) menyatakan ide matematika melalui ucapan, tulisan, demonstrasi, dan melukiskannya secara visual dalam tipe yang berbeda, (2) Kemampuan memahami, menafsirkan, dan menilai ide yang disajikan dalam tulisan, lisan, atau dalam bentuk visual, (3) menkonstruk, menafsirkan dan menghubungkan bermacammacam representasi ide dan hubungannya.

Menurut Sullivan \& Mousley (1996: 398), komunikasi matematik bukan hanya sekedar menyatakan ide melalui tulisan tetapi lebih luas lagi yaitu kemampuan siswa dalam hal bercakap, menjelaskan, menggambarkan, mendengar, menanyakan, klarifikasi, bekerja sama (sharing), menulis, dan akhirnya melaporkan apa yang telah dipelajari. NCTM (1989) menjelaskan bahwa "communication in mathematics means that one is able to use its vocabulary, notation, and structure to express and understand ideas and relationship. In this sense, communicating mathematics is integral to knowing and doing mathematics." Hal ini berarti komunikasi 
matematik dapat terjadi ketika siswa belajar dalam kelompok, ketika siswa menjelaskan suatu algoritma untuk memecahkan suatu persamaan, ketika siswa menyajikan cara unik untuk memecahkan masalah, ketika siswa mengkonstruk dan menjelaskan suatu representasi grafik terhadap fenomena dunia nyata, atau ketika siswa memberikan suatu konjektur tentang gambar-gambar geometri (NCTM, 1991: 96).

Untuk mengembangkan kemampuan komunikasi dalam pembelajaran matematika, NCTM (2000: 63) menyatakan bahwa program pembelajaran matematika sekolah harus memberi kesempatan kepada siswa untuk:

1. Menyusun dan mengaitkan mathematical thinking mereka melalui komunikasi.

2. Mengkomunikasikan mathematical thinking mereka secara logis dan jelas kepada teman-temannya, guru, dan orang lain.

3. Menganalisis dan menilai mathematical thinking dan strategi yang dipakai orang lain.

4. Menggunakan bahasa matematika untuk mengekspresikan ide-ide matematika secara benar.

Menurut NCTM (2000: 194) kemampuan komunikasi seharusnya meliputi berbagi pemikiran, menanyakan pertanyaan, menjelaskan pertanyaan dan membenarkan ide-ide. Komunikasi harus terintegrasi dengan baik pada lingkungan kelas. Siswa harus didorong untuk menyatakan dan menuliskan dugaan, pertanyaan dan solusi

Ansari (2003) menelaah kemampuan Komunikasi matematika dari dua aspek yaitu komunikasi lisan (talking) dan komunikasi tulisan (writing). Komunikasi lisan diungkap melalui intensitas keterlibatan siswa dalam kelompok kecil selama berlangsungnya proses pembelajaran. Sementara yang dimaksud dengan komunikasi matematika tulisan (writing) adalah kemampuan dan keterampilan siswa menggunakan kosa kata (vocabulary), notasi dan struktur matematika untuk menyatakan hubungan dan gagasan serta memahaminya dalam memecahkan masalah. Kemampuan ini diungkap melalui representasi matematika. Representasi matematika siswa diklasifikasikan dalam tiga kategori:

a. Pemunculan model konseptual, seperti gambar, diagram, tabel dan grafik (aspek drawing)

b. Membentuk model matematika (aspek mathematical expression)

c. Argumentasi verbal yang didasari pada analisis terhadap gambar dan konsepkonsep formal (aspek written texts).

Sumarmo (2010:6) menuliskan kegiatan yang tergolong pada komunikasi matematis di antaranya adalah: (1) menyatakan suatu situasi, gambar, diagram, atau benda nyata ke dalam bahasa, simbol, idea, atau model matematik; (2) menjelaskan idea, situasi, dan relasi matematika secara lisan atau tulisan; (3) mendengarkan, berdiskusi, dan menulis tentang matematika; (4) membaca dengan pemahaman suatu representasi matematika tertulis; (5) mengungkapkan kembali suatu uraian atau paragrap matematika dalam bahasa sendiri.

Selain itu, Sumarmo (2003: 6) juga menyatakan bahwa kemampuan komunikasi matematika merupakan kemampuan yang dapat menyertakan dan memuat berbagai kesempatan untuk berkomunikasi dalam bentuk:

1. Merefleksikan benda-benda nyata, gambar, dan diagram ke dalam ide matematika.

2. Membuat model situasi atau persoalan menggunakan metode lisan, tertulis, konkrit, grafik, dan aljabar.

3. Menyatakan peristiwa sehari-hari dalam bahasa atau simbol matematika.

4. Mendengarkan, berdiskusi, dan menulis tentang matematika. 
5. Membaca dengan pemahaman suatu presentasi matematika tertulis.

6. Membuat konektor, menyusun argumen, merumuskan definisi, dan generalisasi.

7. Menjelaskan dan membuat pertanyaan tentang matematika yang telah dipelajari.

Indikator komunikasi matematik dalam penelitian ini adalah (1) Menyatakan suatu situasi ke dalam model matematika, (2) Membuat suatu situasi masalah ke dalam bahasa sendiri, dan (3) Menyatakan ide matematis secara tulisan.

\section{Strategi Pembelajaran Think Talk Write (TTW)}

Strategi TTW diperkenalkan oleh Huinker \& Laughlin (1996:82) yang pada dasarnya dibangun melalui tiga aktivitas utama yaitu berpikir, berbicara dan menulis. Alur strategi TTW dimulai dari keterlibatan siswa dalam berpikir atau berdialog dengan dirinya sendiri setelah proses membaca, selanjutnya berbicara dan membagi ide (sharing) dengan temannya dalam diskusi, dan menuliskan hasil dari proses pembelajaran tersebut.

Aktivitas berpikir, berbicara, dan menulis dalam pembelajaran matematika merupakan aktivitas yang dapat memberi kesempatan kepada siswa untuk lebih aktif selama proses pembelajaran. Melalui aktivitas ini siswa dapat belajar melatih kemampuan berpikirnya, menggunakan bahasa yang tepat dan komunikatif pada saat menyampaikan ide atau mengkritisi pendapat siswa lain, dan belajar menuangkan hasil yang diperolehnya ke dalam bentuk tulisan.

\section{Berpikir (think)}

Menurut Suryabrata (1990: 54) berpikir merupakan proses yang dinamis yang dapat dilukiskan menurut proses atau jalannya. Berpikir adalah proses yang dimulai dari penemuan informasi baik dari dalam ataupun dari luar diri siswa, penyimpanan informasi, dan pemanggilan kembali informasi (Marpaung, 1986: 6). Dalam proses berpikir, terjadi pembentukan pengertian, pembentukan pendapat, dan penarikan kesimpulan.

Berpikir yang dilakukan manusia menurut Marzuki (2006: 27) meliputi:

a. Metakognisi, merupakan kesadaran seseorang tentang proses berpikirnya pada saat melakukan tugas tertentu dan kemudian menggunakan kesadaran tersebut untuk mengontrol apa yang dilakukan.

b. Berpikir kritis dan kreatif, merupakan dua komponen yang sangat mendasar. Berpikir kritis merupakan proses penggunaan kemampuan berpikir secara efektif yang dapat membantu seseorang untuk membuat, mengevaluasi, serta mengambil keputusan tentang apa yang diyakini serta dilakukan. Sedangkan berpikir kreatif merupakan kemampuan yang bersifat spontan, terjadi karena adanya arahan yang bersifat internal dan keberadaannya tidak bisa diprediksi.

c. Proses berpikir, memiliki delapan komponen utama yaitu pembentukan konsep, pembentukan prinsip, pemahaman, pemecahan masalah, pengambilan keputusan, penelitian, penyusunan, dan berwacana secara oral.

d. Kemampuan berpikir utama, juga memiliki delapan komponen yaitu kemampuan memfokuskan, kemampuan mendapatkan informasi, kemampuan mengingat, kemampuan mengorganisasikan, kemampuan menganalisis, kemampuan menghasilkan, kemampuan mengintegrasi, serta kemampuan mengevaluasi.

e. Berpikir matematik tingkat tinggi, pada hakekatnya merupakan non prosedural yang mencakup kemampuan mencari dan mengeksplorasi pola, kemampuan menggunakan fakta-fakta, kemampuan membuat ide-ide matematika, kemampuan berpikir dan bernalar secara 
fleksibel, serta menetapkan bahwa suatu pemecahan masalah bersifat logis.

Proses berpikir dalam strategi TTW diawali dengan kegiatan membaca teks matematika, baik berupa penjelasan maupun permasalahan. Siswa secara individu mencoba memikirkan kemungkinan penyelesaian atau ide-ide yang berkaitan dengan bacaan, kemudian membuat catatan tentang hal-hal yang didapatkannya dengan bahasa yang dipahami.

Menurut Wiederhold, melalui pembuatan catatan, siswa dapat menganalisis tujuan isi teks, dan memeriksa bahan-bahan yang ditulis (Ansari, 2003:36). Hal ini tentu dapat menambah pengetahuan dan daya ingat siswa karena siswa akan memahami dengan baik tentang proses sebelum menulis, ketika menulis, dan setelah menulis.

\section{Berbicara (talk)}

Berbicara dalam TTW yaitu berkomunikasi dengan menggunakan bahasa yang dipahami oleh siswa baik bahasa formal ataupun bahasa non formal yang baik. Siswa dilatih untuk percaya diri mengungkapkan sesuatu yang diperolehnya dari aktivitas think termasuk mengkritisi perolehan siswa lain.

Dalam strategi TTW, berbicara dilakukan dalam bentuk diskusi. Diskusi dilakukan untuk bertukar ide dan melengkapi pengetahuan. Diskusi juga dilakukan untuk meningkatkan pemahaman karena ketika siswa berbicara atau berdialog, mereka dapat mengkonstruksi berbagai ide yang muncul dari kegiatan diskusi. Adapun kelebihan dari diskusi kelas secara rinci adalah sebagai berikut:

a. Dapat mempercepat pemahaman materi pambelajaran dan kemahiran menggunkan strategi.

b. Membantu siswa mengkonstruksi matematika.

c. Menginformasikan bahwa para ahli matematika biasanya tidak memecahkan masalah sendiri-sendiri, tetapi membangun ide bersama pakar lainnya dalam satu tim.

d. Membantu siswa menganalisis dan memecahkan masalah secara bijaksana.

Melalui aktivitas berbicara keterlibatan siswa dalam pembelajaran dapat terlihat dengan jelas. Siswa dapat menjadi lebih aktif dan percaya diri. Siswa dapat berlatih untuk terampil dalam berbicara. Menurut Ansari (2003: 37) talk merupakan kegiatan yang penting dalam belajar matematika. Hal ini disebabkan oleh:

a. Apakah itu tulisan, gambaran, isyarat, atau percakapan merupakan perantara ungkapan matematika sebagai bahasa manusia? Matematika adalah bahasa yang spesial dibentuk untuk mengkomunikasikan bahasa sehari-hari.

b. Pemahaman matematika dibangun melalui interaksi dan konversasi (percakapan) antara sesama individual yang merupakan aktivitas sosial yang bermakna.

c. Cara utama partisipasi komunikasi dalam matematika ialah melalui talk. Siswa menggunakan bahasa untuk menyajikan ide kepada temannya, membangun teori bersama, sharing strategi solusi, dan membuat definisi.

d. Pembentukan ide (forming ideas) melalui proses talking. Dalam proses ini, pikiran sering kali dirumuskan, diklarifikasi, atau direvisi.

e. Internalisasi ide (internalizing ideas). Dalam proses konversasi matematika internalisasi dibentuk melalui berpikir dan memecahkan masalah. Siswa mungkin mengadopsi strategi yang lain, mereka mungkin bekerja dengan memecahkan bagian dari soal yang lebih mudah, mereka mungkin belajar frasefrase yang dapat membantu mereka mengarahkan pekerjaannya.

f. Meningkatkan dan menilai kualitas berpikir. Talking membantu guru mengetahui tingkat pemahaman siswa 
dalam belajar matematika, sehingga dapat mempersiapkan perlengkapan pebelajaran yang dibutuhkan.

3. Menulis (write)

Aktivitas yang terakhir yaitu menulis (write). Pada aktivitas menulis, siswa menuliskan hasil diskusi pada lembar kerja yang disediakan. Siswa menkonstruksi kembali ide, karena setelah berdiskusi dengan temannya, mereka mengungkapkannya melalui tulisan (Ansari, 2003: 36).

Adapun rincian kegiatan yang dilakukan siswa selama tahap menulis diungkapkan oleh Ansari (2003: 39) yaitu:

a. Menulis solusi terhadap masalah atau pertanyaan yang diberikan.

b. Mengorganisasikan semua pekerjaan langkah demi langkah, baik penyelesaiannya ada yang menggunakan diagram, grafik, ataupun tabel agar mudah dibaca dan ditindaklanjuti.

c. Mengkoreksi semua pekerjaan sehingga yakin tidak ada pekerjaan ataupun perhitungan yang ketinggalan

d. Meyakini bahwa pekerjaannya yang terbaik yaitu lengkap, mudah dibaca, dan terjamin keasliannya.

Apabila aktivitas think, talk, dan write dilakukan secara optimal oleh suatu grup siswa, maka pembelajaran dapat berlangsung efektif karena tiap anggota dari sebuh grup dapat saling membantu, dan tiap grup dari seluruh grup dapat berpartisipasi aktif untuk saling mengkritisi dan melengkapi hingga diperoleh sesuatu secara utuh.

Untuk mengoptimalkan hasil dari strategi TTW, ada beberapa hal yang dapat dilakukan oleh guru. Menurut Silver dan Smith (dalam Ansari, 2003), hal-hal tersebut adalah:

a. Mengajukan pertanyaan dan tugas yang mendatangkan keterlibatan dan menantang setiap siswa perpikir.

b. Mendengarkan secara hati-hati ide siswa.

c. Mengajak siswa mengemukakan ide secara lisan dan tulisan. d. Memutuskan apa yang digali dan dibawa siswa dalam diskusi.

e. Memutuskan kapan memberi informasi, mengklarifikasi persoalan-persoalan, menggunakan model, membimbing, dan membiarkan siswa berjuang dengan kesulitan.

f. Memonitoring dan menilai partisipasi siswa dalam diskusi, dan memutuskan kapan dan bagaimana mendorong setiap siswa untuk berpartisipasi.

Untuk mewujudkan suatu pembelajaran yang diharapkan dapat menjawab pokok permasalahan dalam penelitian ini, dirancang suatu desain pembelajaran dengan strategi think talk write, dengan langkah-langkah kegiatan sebagai berikut:

a. Guru membagikan Lembar Kerja Siswa yang memuat suatu permasalahan dan petujuk pelaksanaannya. Siswa membaca teks, memikirkan, dan mencari gambaran solusi dari permasalahan tersebut, kemudian menuangkannya dalam catatan (think).

b. Guru membagi siswa kedalam beberapa kelompok yang beranggotakan masingmasing 3-4 orang. Setelah itu, siswa berinteraksi dan berdiskusi dengan kelompok kecilnya mengenai isi catatan individunya. Pada bagian ini, siswa diharapkan mulai aktif berbicara dan saling membantu satu sama lain dalam satu kelompok (talk).

c. Siswa mengkonstruksi pengetahuan yang didapatkannya dalam diskusi kelompok, menuliskan kesepakatan kelompoknya untuk disajikan dalam diskusi kelas melalui presentasi, dan menuliskan hasil yag diperoleh selama pembelajaran (write).

\section{METODE}

Penelitian yang digunakan adalah kuasi eksperimen. Desain penelitiannya menggunakan desain kelompok kontrol nonekuivalen. 
O X O (Ruseffendi, 2005:53)

\section{O O}

Keterangan:

$\mathrm{O}$ : Tes kemampuan komunikasi matematik siswa

$\mathrm{X}$ : Strategi pembelajaran think talk write

... : Pengambilan sampel tidak secara acak

Penelitian ini dilakukan di salah satu

MTs di Kabupaten Garut. Penelitian dilaksanakan dari bulan September 2014 sampai dengan bulan Februari 2015.

\section{HASIL DAN PEMBAHASAN}

Tabel 1. Data Statistik Skor Kemampuan Komunikasi Matematik

\begin{tabular}{|c|c|c|c|c|c|}
\hline \multirow{2}{*}{$\begin{array}{c}\text { Varia- } \\
\text { bel }\end{array}$} & \multirow{2}{*}{$\begin{array}{c}\text { Dat } \\
\text { a } \\
\text { Stati } \\
\text { s-tik }\end{array}$} & \multicolumn{2}{|c|}{$\begin{array}{c}\text { Kelas } \\
\text { Eksperimen }\end{array}$} & \multicolumn{2}{|c|}{ Kelas Kontrol } \\
\hline & & Pretes & Posttes & Pretes & Posttes \\
\hline \multirow{6}{*}{$\begin{array}{c}\text { Kema } \\
\text { m-puan } \\
\text { Komun } \\
\text { i-kasi } \\
\text { Matem } \\
\text { a-tik }\end{array}$} & $N$ & 34 & 34 & 34 & 34 \\
\hline & $\mathrm{X}_{\max }$ & 8 & 15 & 8 & 10 \\
\hline & $\mathrm{X}_{\min }$ & 1 & 9 & 1 & 5 \\
\hline & $\bar{x}$ & 3,94 & 12,06 & 4,00 & 7,50 \\
\hline & $(\%)^{*}$ & $(26,27)$ & $(80,40)$ & $(26,67)$ & $(50,00)$ \\
\hline & SD & 1,84 & 1,79 & 1,80 & 1,44 \\
\hline
\end{tabular}

Berdasarkan tabel 1 di atas, dapat dilihat bahwa hasil rerata pretes kemampuan komunikasi matematik kelas eksperimen sebesar 3,94 dan kelas kontrol 4,00. Dari kedua data tersebut diperoleh selisih sebesar 0,06. Nilai selisih tersebut tidak terlalu besar sehingga dapat diduga bahwa kedua kelas mempunyai kemampuan awal komunikasi matematik yang tidak jauh berbeda. Hal ini berbeda dengan hasil rerata posttest kemampuan komunikasi matematik, dimana rerata kelas eksperimen sebesar 12,06 dan kelas kontrol 7,50 dengan selisih cukup besar yaitu sebesar 4,56. Dari selisih tersebut dapat diduga bahwa kemampuan akhir komunikasi matematik kedua kelas berbeda. Jika dilihat dari besar nilai reratanya, tampak bahwa rerata kemampuan komunikasi matematik kelas eksperimen lebih tinggi daripada kelas kontrol.

\section{Analisis hasil pretes dan postes kemampuan komunikasi matematik}

Tabel 2. Hasil Uji Normalitas Skor Pretes Kemampuan Komunikasi Matematik Siswa Kelas Eksperimen dan Kelas Kontrol

Tests of Normality

\begin{tabular}{|c|c|c|c|c|c|c|c|}
\hline & \multirow[b]{2}{*}{ kelas } & \multicolumn{3}{|c|}{ Kolmogoror-Smirnore } & \multicolumn{3}{|c|}{ Shapiro-Wilk } \\
\hline & & Statistic & $d f$ & Sig. & Statistic & $d f$ & Sig. \\
\hline \multirow[t]{2}{*}{ skor } & PM_Pre_Eks & .137 & 34 & .109 & .947 & 34 & .099 \\
\hline & PM_Pre_Kon & .122 & 34 & $.200^{\prime}$ & .950 & 34 & .125 \\
\hline
\end{tabular}

Berdasarkan tabel 2 di atas, dapat dilihat bahwa nilai signifikansi (Sig.) kelas eksperimen sebesar 0,099 dan kelas kontrol sebesar 0,125. Nilai signifikansi (Sig.) kedua kelas ternyata lebih besar dari 0,05 atau dengan kata lain sig > 0,05 sehingga $\mathrm{H}_{0}$ diterima. Hal ini berarti pada taraf kepercayan 95\% skor pretes kemampuan komunikasi matematik pada kelas eksperimen dan kontrol berdistribusi normal.

Uji statistik selanjutnya terhadap hasil pretes kemampuan komunikasi matematik yaitu uji homogenitas. Uji homogenitas dilakukan dengan bantuan software SPSS 18.0 dengan uji Levene.

Tabel 3. Hasil Uji Homogenitas Varians Skor Pretes Kemampuan Komunikasi Matematik Siswa Kelas Eksperimen dan Kelas Kontrol Test of Homogeneity of Variance

\begin{tabular}{|l|r|r|r|r|}
\hline & \multicolumn{1}{|c|}{$\begin{array}{c}\text { Levene } \\
\text { Statistic }\end{array}$} & \multicolumn{1}{c|}{ df1 } & \multicolumn{1}{c|}{ df2 } & \multicolumn{1}{c|}{ Sig. } \\
\hline skor $\quad$ Based on Mean & .062 & 1 & 66 & .804 \\
& .049 & 1 & 66 & .825 \\
Based on Median & .049 & 1 & 65.967 & .825 \\
Based on Median and & .054 & 1 & 66 & .817 \\
with adjusted df & & & \\
Based on trimmed mean & & &
\end{tabular}

Berdasarkan tabel 3 di atas, dapat dilihat bahwa nilai signifikansi (Sig.) lebih besar dari 0,05 yaitu 0,804 atau dengan kata lain sig > 0,05 sehingga $\mathrm{H}_{0}$ diterima. Hal ini berarti varians skor pretes kemampuan komunikasi matematik kedua kelas homogen. 
Uji yang terakhir terhadap hasil pretes yaitu uji perbedaan rerata skor pretes. Tujuannya yaitu untuk mengetahui apakah terdapat perbedaan kemampuan awal pada kelas kontrol dan eksperimen. Uji tersebut dilakukan dengan bantuan software SPSS 18.0 yaitu uji- $t$.

Tabel 4. Hasil Uji Perbedaan Rerata Skor Pretes Kemampuan Komunikasi Matematik Siswa Kelas Eksperimen dan Kelas Kontrol Independent Samples Test

\begin{tabular}{|c|c|c|c|c|}
\hline & & & \multicolumn{2}{|c|}{ skor } \\
\hline & & & $\begin{array}{c}\text { Equal } \\
\text { variances } \\
\text { assumed } \\
\end{array}$ & $\begin{array}{c}\text { Equal } \\
\text { variances not } \\
\text { assumed }\end{array}$ \\
\hline $\begin{array}{l}\text { Levene's Test for Equality } \\
\text { of Variances }\end{array}$ & $\begin{array}{l}F \\
\text { Sig. }\end{array}$ & & $\begin{array}{l}.062 \\
.804 \\
\end{array}$ & \\
\hline $\begin{array}{l}\text { t-test for Equality of } \\
\text { Means }\end{array}$ & $\begin{array}{l}\text { t } \\
\text { df } \\
\text { Sig. (2-tailed) } \\
\text { Mean Difference } \\
\text { Std. Error Difference } \\
95 \% \text { Confidence Interval } \\
\text { of the Difference }\end{array}$ & $\begin{array}{l} \\
\text { Lower } \\
\text { Upper }\end{array}$ & $\begin{array}{r}-.133 \\
66 \\
.895 \\
.059 \\
.443 \\
.943 \\
.825 \\
\end{array}$ & $\begin{array}{r}-.133 \\
65.979 \\
.895 \\
-.059 \\
.443 \\
.943 \\
.825 \\
\end{array}$ \\
\hline
\end{tabular}

Berdasarkan tabel 4 di atas, dapat dilihat bahwa nilai signifikansi (Sig.) lebih besar dari 0,05 yaitu 0,895 atau dengan kata lain sig > 0,05 sehingga berdasarkan kriteria pengujian di atas maka $\mathrm{H}_{0}$ diterima atau tidak terdapat perbedaan rerata skor pretes kemampuan komunikasi matematik antara siswa di kelas eksperimen dan di kelas kontrol. Hal tersebut berarti pada tingkat kepercayaan $95 \%$, tidak terdapat perbedaan kemampuan awal komunikasi matematik antara siswa di kelas eksperimen dan di kelas kontrol.

Tabel 5. Hasil Uji Normalitas Skor Postes Kemampuan Komunikasi Matematik Siswa Kelas Eksperimen dan Kelas Kontrol Tests of Normality

\begin{tabular}{|rl|r|r|r|r|r|r|}
\hline & & \multicolumn{3}{|c|}{ Kolmogoror-Smimor } & \multicolumn{3}{|c|}{ Shapiro-Wilk } \\
\cline { 2 - 7 } & \multirow{2}{*}{ Kelas } & Statistic & \multicolumn{1}{c|}{$\mathrm{df}$} & \multicolumn{1}{c|}{ Sig. } & Statistic & \multicolumn{1}{c|}{ df } & \multicolumn{1}{c|}{ Sig. } \\
\hline skor & PM_Pre_Eks & .142 & 34 & .082 & .944 & 34 & .082 \\
& PM_Pre_Kon & .136 & 34 & .115 & .941 & 34 & .066 \\
\hline
\end{tabular}

a. Lilliefors Significance Correction

Berdasarkan tabel 5 di atas, dapat dilihat bahwa nilai signifikansi (Sig.) kelas eksperimen sebesar 0,082 dan kelas kontrol sebesar 0,066. Nilai signifikansi (Sig.) kedua 110 kelas ternyata lebih besar dari 0,05 atau dengan kata lain sig > 0,05 sehingga berdasarkan kriteria di atas maka Ho diterima. Hal ini berarti pada taraf kepercayan 95\% skor postes kemampuan komunikasi matematik pada kelas eksperimen dan kontrol berdistribusi normal.

Uji statistik selanjutnya terhadap hasil postes kemampuan komunikasi matematik yaitu uji homogenitas dengan bantuan software SPSS 18.0 dengan uji Levene.

Tabel 6. Hasil Uji Homogenitas Varians Skor Postes Kemampuan Komunikasi Matematik Siswa Kelas Eksperimen dan Kelas Kontrol Test of Homogeneity of Variance

\begin{tabular}{|ll|r|r|r|r|}
\hline & \multicolumn{1}{|c|}{$\begin{array}{l}\text { Levene } \\
\text { Statistic }\end{array}$} & \multicolumn{1}{c|}{$\mathrm{df1}$} & \multicolumn{1}{c|}{$\mathrm{d}$ f2 } & \multicolumn{1}{c|}{ Sig. } \\
\hline skor & Based on Mean & 1.632 & 1 & 66 & .206 \\
& Based on Median & 1.526 & 1 & 66 & .221 \\
& Based on Median and & 1.526 & 1 & 61.813 & .221 \\
& with adjusted df & 1.644 & 1 & 66 & .204 \\
\hline
\end{tabular}

Berdasarkan tabel 6 di atas, dapat dilihat bahwa nilai signifikansi (Sig.) lebih besar dari 0,05 yaitu 0,206 atau dengan kata lain sig > 0,05 sehingga berdasarkan kriteria pengujian di atas maka $\mathrm{H}_{0}$ diterima. Hal ini berarti varians skor postes kemampuan komunikasi matematik kedua kelas homogen.

\section{PENUTUP}

\section{Kesimpulan}

Pencapaian kemampuan komunikasi matematik siswa yang memperoleh pembelajaran think talk write lebih baik daripada siswa yang memperoleh pembelajaran konvensional.

\section{Saran}

Berdasarkan kesimpulan penelitian, peneliti mengajukan beberapa saran sebagai berikut:

1. Strategi pembelajaran think talk write direkomendasikan menjadi alternatif pembelajaran di jenjang SMP dalam 
upaya mengembangkan kemampuan komunikasi matematik siswa.

2. Pada penelitian ini dikaji pencapaian kemampuan komunikasi matematik secara keseluruhan, direkomendasikan pada penelitian lainnya untuk mengkaji pencapaian kemampuan komunikasi matematik siswa berdasarkan kemampuan awal siswa baik kategori tinggi, sedang, dan rendah.

\section{DAFTAR PUSTAKA}

Anggraeni, D. (2012). Meningkatkan Kemampuan Pemahaman Dan Komunikasi Matematik Siswa SMK Melalui Pendekatan Kontekstual Dan Strategi Formulate-ShareListen-Create (FSLC). Tesis pada Sekolah Pasca Sarjana UPI: tidak diterbitkan.

Ansari, B. I. (2003). Menumbuh Kembangkan Kemampuan Pemahaman Dan Komunikasi Matematika Siswa Melalui Strategi Think-Talk-Write: Studi Eksperimen pada Siswa Kelas 1 SMUN di Kota Bandung . Disertasi pada Sekolah Pasca Sarjana UPI: tidak diterbitkan. Baroody, A.J. (1993). Problem Solving, Reasoning and Communicating. $K$ 8: Helping Children Think Mathematically. New York: MacMillan Publishing Company.

Depdiknas. (2005). Peraturan Pemerintah Nomor 19 Tahun 2005 tentang Standar Nasional Pendidikan. Jakarta: Departemen Pendidikan Nasional.

Depdiknas. (2006). Kurikulum Tingkat Satuan Pendidikan (KTSP). Jakarta: Depdiknas.

Greenes, C \& Schulman, L. (1996). Communication Process in Mathematical Exploration and Investigation. In P. C. Elliot and M.
J. Kenney (Eds.) 1996 Yearbook. Communication in Mathematics, K12 and Beyond. USA: NCTM.

Huinker, D. dan Laughlin, C. (1996). Talk Your Way into Writing. In P. C. Elliott, and M. J. Kenney (Eds). 1996. Yearbook. Communication in Mathematics, K-12 and Beyond. USA: NCTM.

Lindquist, M.M. \& Elliot, P.C. (1996). Communication-an Imperative for Change: A Conversation with Mary Lindquist. Dalam P.C Elliot dan M.J Kenney (Eds). Yearbook Communication in Mathematics K12 and Beyond. Virginia: The National Council of Teachers of Mathematics.

National Council of Teachers of Mathematics. (1989). Curriculum and Evaluation Standards for School Mathematics. Reston, VA: NCTM.

. (1991). Proffesional Standards for Teaching Mathematics. Reston, VA: NCTM . (2000). Principle and Strandars for School Mathematics. United States: NCTM.

Osterholm, M. (2006). Metakognition and reading-criteria for comprehension of mathematics texts. In Novotna, J., Moraova, H., Kratka, M. \& Stehlikova, N. (Eds.). Proceedings 30th Conference of the Internatinal Group for the Psychology of Mathematics Education, Vol. 4, pp. 289-296. Prague: PME.

Marpaung, Y. (1986). Proses Berpikir Siswa dalam Pembentukan Konsep Algoritma Matematis. Makalah Pidato Dies Natalies XXXI IKIP Sanata Dharma Salatiga, 25 Oktober 1986.

Maryani, N. (2011). Pencapaian kemampuan komunikasi matematis 
siswa melalui pembelajaran dengan strategi SQ3R (studi eksperimen SMA Negeri kabupaten garut). Tesis. pada Sekolah Pasca Sarjana UPI: tidak diterbitkan.

Marzuki, A. (2006). Implementasi Pembelajaran Cooperative (Cooperative Learning) dalam Upaya Meningkatkan Kemampuan Koneksi dan Pemecahan Masalah Matematik Siswa. Tesis pada Sekolah Pasca Sarjana UPI: tidak diterbitkan.

Priyambodo, S. (2008). Meningkatkan Kemampuan Komunikasi dan Pemecahan Masalah Matematika siswa SMP melalui Strategi Heuristik. Tesis pada Sekolah Pasca Sarjana UPI: tidak diterbitkan.

Russefendi, H. E. T. (2005). Dasar-Dasar Penelitian Pendidikan \& Bidang Non-Eksakta Lainnya. Bandung: Tarsito.

Satriawati, G. 2006. Pembelajaran Dengan Pendekatan Open Ended Untuk Meningkakan Pemahaman dan Kemampuan Komunikasi Matematika Siswa SMP Jakarta (Studi eksperimen di SMP Bakti Mulya 400 Jakarta Selatan). Tesis pada Sekolah Pasca Sarjana UPI: tidak diterbitkan.

Schoen, H. L., Bean, D. L., \& Ziebarth, S. W. (1996). Embedding Communication throught the Curriculum. In P. C. Elliot and M. J. Kenney (Eds.) 1996 Yearbook. Communication in Mathematics, K12 and Beyond. Reston, VA: NCTM.

Sulvian, P. \& Mousley, J. (1996). "Natural Communication in Mathematics Classroom: Whats Does it Look Like". In P. C. Clarkson. (Ed.). Technology in Mathematics Education. Melbourne: Merga
Sumarmo, U. (2013). Kumpulan Makalah Berpikir dan Disposisi Matematika serta Pembelajarannya. Jurusan Pendidikan Matematika : FMIPA UPI.

- (2010). Pendidikan Karakter, Berpikir dan Disposisi Logis, Kritis, dan Kreatif dalam Pembelajaran Matematika. Makalah pada perkuliahan Evaluasi Matematika 2011 SPS UPI: Tidak Diterbitkan. . (2003). Pembelajaran Matematika untuk Mendukung Pelaksanaan Kurikulum Berbasis Kompetensi. Makalah pada Pelatihan Guru Matematika, Jurusan Matematika ITB Bandung.

Suryabrata, S. (1990). Psikologi Pendidikan. Jakarta: Rajawali Press.

Trends in International Mathematics and Science Study. (2007). International Mathematics Report: Findings from IEA's Trends in International Mathematics and Science Study the Fourth and Eight Grades. Boston: TIMSS \& PIRLS International Study Center.

\section{RIWAYAT HIDUP PENULIS}

Reni Nuraeni, M.Pd. Lahir pada tanggal

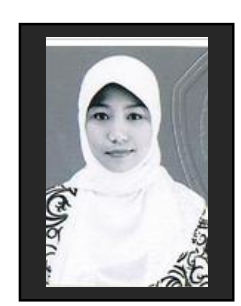
15 Agustus 1988. Dosen Tetap STKIP Garut. Studi S1 Pendidikan Matematika STKIP Garut, lulus tahun 2010; dan S2 Pendidikan Matematika UPI, Bandung, lulus tahun 2014.

Irena Puji Luritawaty, M.Pd. Lahir pada

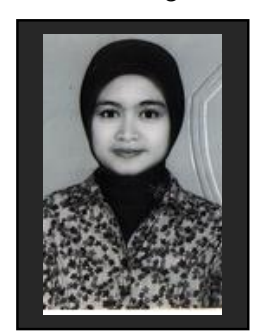
tanggal 30 April 1988. Dosen Tetap Yayasan STKIP Garut. Studi S1 Pendidikan Matematika STKIP Garut, lulus tahun 2010; dan S2 Pendidikan Matematika

UPI, Bandung, lulus tahun 2014. 